\title{
Resilience And Academic Achievement Of Male And Female Secondary Level Students In Pakistan
}

Muhammad Sarwar, University of Sargodha, Pakistan Hafiz Inamullah, University of Peshawar, Pakistan

Naeemullah Khan, Punjab Education Dept., Pakistan

Nadeem Anwar, University of Sargodha, Pakistan

\begin{abstract}
Resilience is the ability to succeed despite barriers that make it difficult for the students to succeed. The purpose of this study was to investigate the relationship between resilience and academic achievement of secondary level students of Gujranwala, Pakistan. A Resilience scale was used to collect data. The sample consisted of 127 secondary students, including 52 boys and 75 girls. The data revealed that there was no association between resilience and achievement as measured through marks obtained in $10^{\text {th }}$ grade. The boys are more resilient than girls at the secondary level in Pakistan.
\end{abstract}

Keywords: Resilience, academic achievement, gender, residence, secondary, Pakistan

\section{INTRODUCTION}

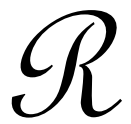

esilience refers to the ability to bounce back and overcome the stress or successful adaptation to the challenging and threatening circumstances/environment. Resilience helps to succeed academically despite barriers that make it difficult for them to succeed (Benard, 1991). Resilient students experience one or more difficult life circumstances or traumatic events, but somehow find the power to overcome their adverse impact (Bryan, 2005). Resilience helps students to successfully deal with academic setbacks, stress, and study pressures during the learning process.

Mclaren and Challis (2009) investigated resilience among Australian men farmers for the prediction of suicidal ideation from depression (the risk factor) and social support and sense of belonging (the protective factors). A sample of 99 Australian men farmers completed measures of depression, suicidal ideas, social support, and sense of belonging. Sense of belonging compensated for high levels of depression, and social support. Sense of belonging and an increasing number of protective factors each weakened the depression-suicidal ideation relation.

Ahern et al (2006) determined that resilience scale was the best instrument to study resilience in the adolescent population due to psychometric properties of the instrument and applications in a variety of age groups, including adolescence. Resilience can be predicted by student's relationships with adults and peers. According to Kimberly and Gordon (2001), the resilient students get more GPA than their non-resilient counterparts coming from the same socio-economic status.

Dass-Brailsford (2005) studied a group of black youth in South Africa who experienced poverty achieved academic success and found that being goal orientated, family support, role models, and teachers were protective factors against hardships. Lundman, et al (2007) concluded that the resilience is related to age; the older, the stronger the resilience. Educators can play a role for the development and reinforcement of resilience-building skills (Morrison and Allen, 2007). 
Many students in America from poor families, who are otherwise likely to drop out, manage to succeed by demonstrating academic resilience in the face of an array of obstacles (Driscoll, Undated). Uzma (2007) found no relationship between academic resilience and academic achievement of postgraduate students at the University of Sargodha (Pakistan) and female students were more resilient than their male counterparts.

Wagnlid and Collins (2009) found positive relationships between resilience and academic success. Academic achievement is a very complex variable and many variables influence it. Researches indicate that the impact of achievement is catalytic for resilience, which may help stakeholders improve the quality and outcome of resilience. Therefore, the results of the study may help us have a more clear understanding of the relationship between resilience and the academic performance. In Pakistan, there is need for identifying a student's resiliency level and fostering it with the help of different strategies and guidelines. This study may help the educators, practitioners, teachers, and parents as well, to understand the importance of the resiliency concept and to enhance it. In light of the above discussion, the objectives of this study were to explore the correlation between academic achievement and resilience, to compare resilience score of male and female students, and to compare resilience of rural and urban students.

Table 1: Factor Solution Showing the Distribution and Loading of Items

\begin{tabular}{|c|c|c|c|c|c|}
\hline Items & 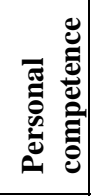 & 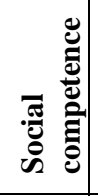 & 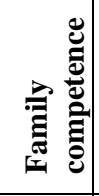 & 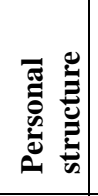 & 焉 \\
\hline I believe in my own abilities & .746 & & & & \\
\hline Believing in myself helps me to overcome difficult times & .573 & & & & \\
\hline I know that I succeed if I carry on & .509 & & & & \\
\hline I know how to reach my goals & .635 & & & & \\
\hline No matter what happens I always find a solution & .692 & & & & \\
\hline I am comfortable together with other persons & .532 & & & & \\
\hline My future seems very good & .530 & & & & \\
\hline I know that I can solve my personal problems & .682 & & & & \\
\hline I am pleased with my self & .539 & & & & \\
\hline I have realistic plans for the future & .536 & & & & \\
\hline I completely trust my judgements and decisions & .520 & & & & \\
\hline At hard times I know that better times will come & & .510 & & & \\
\hline I am good in getting in touch with new people & & .543 & & & \\
\hline I easily establish new friendships & & .633 & & & \\
\hline I easily adjust to new social milieus & & .538 & & & \\
\hline It is easy for me to make other peoples laugh & & .668 & & & \\
\hline I easily laugh & & .720 & & & \\
\hline It is important for me to be flexible in new circumstances & & .627 & & & \\
\hline I experience good relations with both men and women & & & .591 & & \\
\hline There are strong bonds in my family & & & .684 & & \\
\hline I enjoy being with my family & & & .528 & & \\
\hline In my family we enjoy finding common activities & & & .660 & & \\
\hline I have some close friends/family members who really care about me & & & .636 & & \\
\hline I keep up my daily routines even at difficult times & & & .525 & & \\
\hline Even at difficult times my family keeps a positive outlook on the future. & & & & .547 & \\
\hline In my family we have a common understanding of what is important & & & & .553 & \\
\hline I am quickly notified if some family members got into crisis & & & & .610 & \\
\hline I regularly keep in touch with my family & & & & .592 & \\
\hline I prefer to plan my actions & & & & .531 & \\
\hline I have some close friends/family members who back me up & & & & & .716 \\
\hline I always have someone who can help me when needed & & & & & .570 \\
\hline I have some close friends/family members who are good at encouraging me & & & & & .705 \\
\hline There are strong bonds between my friends & & & & & .813 \\
\hline
\end{tabular}




\section{PROCEDURE}

The internal consistency (Cronbach's alpha) was high for all dimensions ranging from .90 to .67 and for all the terms combined (total Alpha $=.94$ ), and the target population of the study was different from the original population of the scale. Therefore, it was decided to replicate the factor analysis. The following five factors (see Table 1) were extracted from the principal component analysis and Varimax rotation method with Kaisar normalization whose Eigen values are greater than 2.00 and factor loadings greater than .5: personal competence, social competence, family competence, personal structure, and social support. In this way, the scale consisted of 33 remaining items; i.e., 11 under the first factor, 7 under the second factor, 6 under the third factor, 5 under the fourth factor, and 4 under the fifth factor. Cronbach's alpha, for each component, is given in Table 2. The cumulative variance, explained by all five factors, is $47.35 \%$. The Eigen value of the first factor is 9.57 and the variance it explains is $22.26 \%$; for the second factor, the results are 3.48 and $8.08 \%$; for the third factor, 3.07 and $7.05 \%$; for the fourth factor, 2.19 and 5.10; and for the fifth factor, the results are 2.05 and $4.76 \%$, respectively.

Table 2: Reliability Estimates for Resilience Scale and Sub-scales

\begin{tabular}{|c|c|c|}
\hline Sr. & Dimension & Cronbach'S Alpha \\
\hline 1 & Personal Competence & .83 \\
\hline 2 & Social Competence & .78 \\
\hline 3 & Family competence & .80 \\
\hline 4 & Personal Structure & .74 \\
\hline 5 & Social support & .80 \\
\hline 6 & Total Resilience & .91 \\
\hline
\end{tabular}

\section{CORRELATION BETWEEN RESILIENCE AND ACADEMIC ACHIEVEMENT}

The analysis of data revealed that there is no correlation $(r=.-014, p<.853)$ between academic achievement and resilience scores, but it varies with achievement. For high achievers, it is negative ( $r=-505, \mathrm{p}<.001)$; for medium achievers, it is positive $(\mathrm{r}=.326, \mathrm{p}<.031)$; and for low achievers, there is no correlation $(\mathrm{r}=.020, \mathrm{p}<.900)$. Furthermore, the correlation between resilience and academic achievement for boys $(r=.-063, \mathrm{p}<.65)$, girls $(\mathrm{r}=-.083$, $\mathrm{p}<.478)$, rural $(\mathrm{r}=.140, \mathrm{p}<.445)$, and urban $(\mathrm{r}=.-077, \mathrm{p}<.459)$ are not significant.

Table 3: Means and Standard Deviations Resilience Scores of Male and Female Students

\begin{tabular}{|c|c|c|c|c|c|c|c|}
\hline Variable & Gender & $\mathbf{N}$ & Mean & Std. Dev. & $\mathbf{T}$ & Df & Sig. (2-tailed) \\
\hline \multirow{2}{*}{ Resilience } & Male & 52 & 139.62 & 17.94 & \multirow{2}{*}{3.44} & \multirow{2}{*}{125} & \multirow{2}{*}{.001} \\
\hline & Female & 75 & 129.35 & 15.50 & & & \\
\hline \multirow{2}{*}{ Personal Competence } & Male & 52 & 48.31 & 7.23 & \multirow{2}{*}{3.16} & \multirow{2}{*}{125} & \multirow{2}{*}{.002} \\
\hline & Female & 75 & 44.93 & 4.82 & & & \\
\hline \multirow{2}{*}{ Social competence } & Male & 52 & 27.23 & 6.18 & \multirow{2}{*}{. .066} & \multirow{2}{*}{125} & \multirow{2}{*}{.947} \\
\hline & Female & 75 & 27.16 & 5.70 & & & \\
\hline \multirow{2}{*}{ Family Competence } & Male & 52 & 25.50 & 4.09 & \multirow{2}{*}{4.85} & \multirow{2}{*}{125} & \multirow{2}{*}{.000} \\
\hline & Female & 75 & 21.35 & 5.14 & & & \\
\hline \multirow{2}{*}{ Personal Structure } & Male & 52 & 21.92 & 3.36 & \multirow{2}{*}{3.06} & \multirow{2}{*}{125} & \multirow{2}{*}{.003} \\
\hline & Female & 75 & 20.00 & 3.56 & & & \\
\hline \multirow{2}{*}{ Social support } & Male & 52 & 16.65 & 3.89 & \multirow{2}{*}{1.08} & \multirow{2}{*}{125} & \multirow{2}{*}{.283} \\
\hline & Female & 75 & 15.91 & 3.81 & & & \\
\hline
\end{tabular}

Table 3 above shows that female and male students at the secondary level differ in their resilience, favouring male students. This difference is significant on all scales, except social competence. 
Table 4: Means and Standard Deviations Resilience Scores of Rural and Urban Students

\begin{tabular}{|c|c|c|c|c|c|c|c|}
\hline Variable & Residence & $\mathbf{N}$ & Mean & Std. Dev. & $\mathbf{T}$ & Df & Sig. (2-tailed) \\
\hline \multirow{2}{*}{ Resilience } & Urban & 95 & 132.86 & 17.12 & \multirow[b]{2}{*}{-.78} & \multirow[t]{2}{*}{125} & \multirow{2}{*}{.440} \\
\hline & Rural & 32 & 135.59 & 17.67 & & & \\
\hline \multirow{2}{*}{ Personal Competence } & Urban & 95 & 45.98 & 6.03 & \multirow{2}{*}{-1.06} & \multirow[t]{2}{*}{125} & \multirow{2}{*}{.289} \\
\hline & Rural & 32 & 47.31 & 6.42 & & & \\
\hline \multirow{2}{*}{ Family Competence } & Urban & 95 & 27.84 & 5.65 & \multirow{2}{*}{2.19} & \multirow[t]{2}{*}{125} & \multirow{2}{*}{.030} \\
\hline & Rural & 32 & 25.25 & 6.20 & & & \\
\hline \multirow{2}{*}{ Social competence } & Urban & 95 & 22.44 & 5.08 & \multirow{2}{*}{-2.23} & \multirow[t]{2}{*}{125} & \multirow{2}{*}{.022} \\
\hline & Rural & 32 & 24.84 & 5.00 & & & \\
\hline \multirow{2}{*}{ Personal Structure } & Urban & 95 & 20.57 & 3.69 & \multirow{2}{*}{-1.18} & \multirow[t]{2}{*}{125} & \multirow{2}{*}{.238} \\
\hline & Rural & 32 & 21.44 & 3.27 & & & \\
\hline \multirow{2}{*}{ Social support } & Urban & 95 & 16.03 & 3.88 & \multirow{2}{*}{-.913} & \multirow[t]{2}{*}{125} & \multirow{2}{*}{.363} \\
\hline & Rural & 32 & 16.75 & 3.74 & & & \\
\hline
\end{tabular}

Table 4 above shows that urban and rural students at the secondary level do not differ in their resilience. This difference is not significant on all scales, except family competence.

\section{CONCLUSION}

1. There is no statistically significant correlation found between academic resilience and academic achievement of secondary school students.

2. Female students are more resilient as compared to male students.

3. There is no difference in the resilience of rural and urban students at the secondary level.

\section{DISCUSSION}

As a whole, there is no correlation found between academic resilience and academic achievement of secondary school students. The relationship changes with academic achievement. For high academic achievers, the correlation is negative; for medium, it is positive; and there is no correlation between resilience and academic achievement of low achievers. Dass-Brailsford (2005) found that a group of black youth in South Africa, who experienced poverty, achieved academic success and were high in resilience. However, in Pakistan, Uzma (2007) found no relationship between resilience and academic achievement of postgraduate students at the University of Sargodha." This makes the situation complex and more research is required on a larger sample to explore the results in greater detail. Male students are more resilient as compared to female students in Pakistan for reasons not measured here. These results are contradictory to Uzma (2007) who found that in Pakistan, female students are more resilient than their male counterparts, which may be that the resilience is related to age (Lundman, et al, 2007). Uzma (2007) conducted her study on post-graduate university students, but in the present study, the students are secondary school level. Due to cultural norms, the females in Pakistan try to be more resilient as they grow older. There is no difference in the resilience of rural and urban students at the secondary level.

\section{AUTHOR INFORMATION}

Muhammad Sarwar, is working as Assistant Professor in Department of Education, University of Sargodha, Pakistan. He has recently completed his post-doctorate from England. He published a number of articles in the journals of national and internal repute. He has worked as lead trainer, course writer and has delivered a number of training sessions to the university and school faculty. His special areas of interest are research and development, achievement studies and demand driven education. He did his MPhil and PhD in Education from Pakistan.

Hafiz M Inamullah is working as Assistant Professor in Institute of Education and Research, University of Peshawar, Pakistan. He has visited USA for a number of times for study purposes. He published a number of articles in the journals of national and internal repute. His special areas of interest are research and development, Madrssah education and higher education. He did his $\mathrm{PhD}$ in Education from University Institute of Education and Research, UAAR, Pakistan. 
Naeemullah Khan, is working as principal in a Government school in Punjab (Pakistan). He is working a visiting professor in the university college of Education, Ghakkar, Punjab (Pakistan). His special areas of interest are staff development, religious education and school studies. He has participated in a number of national and international conferences and published a number of papers in the journals of national and international repute. He did his $\mathrm{PhD}$ in Education from University Institute of Education and Research, UAAR, Pakistan.

Dr. Muhammad Nadeem Anwar is working as Assistant Professor in Education, University of Sargodha, Pakistan. His main areas of interest are management studies, gender issues, and higher education. He has published a number of papers in the journals of national and international repute. He did M.Phil. in Education from Alllama Iqbal Open University, Islamabad, Pakistan and Ph.D. in Education from University Institute of Education and Research, UAAR.

\section{REFERENCES}

1. Ahern, N. R., Kiehl, E. M., Sole, M. L., \& Byers, J. (2006). A review of instruments measuring resilience. Issues in Comprehensive Paediatric Nursing, 29(2), 103-125.

2. Bryan, J. (2005). Fostering educational resilience and academic achievement in urban schools through school-family-community partnerships. Professional School Counselling, 8(3), 219-227.

3. Benard, B. (1991). Fostering resiliency in kids: Protective factors in the family, school, and community. available online at: http://www.hopeworks.org/formation/documents/FosteringResiliency.pdf (accessed 19 January 2010)

4. Dass-Brailsford, P. (2005). An exploration in resiliency: Academic achievement among disadvantaged Black youth in South Africa. South African Journal of Psychology, 35(3), 571-594.

5. Driscoll A. K. (Undated). Academic Resilience among Low SES High School Students. Davis. University of California. Available on line at: http://paa2006.princeton.edu/download.aspx?submissionId=61572 (accessed 18 January 2010)

6. Friborg, O., Hjemdal, O.,Rosenvinge, J.H., and Martinussen, M.(2003)A New rating Scale for Adult resilience: what are the central protective resources behind healthy adjustment?. International journal of methods in psychiatric research, 12(2), 65-76

7. Kimberly A and Gordon ROUSE (2001) Resilient students' goals and motivation. Journal of Adolescence. 24( 4) 461-472

8. Lundman, B., Strandberg, G. Eisemann, M., Gustafson, Y. and Brulin, C.(2007) Psychometric properties of the Swedish version of the Resilience Scale. Scandinavian journal of Caring Sciences. 21(2), 229-237

9. Morrison, G. M., and Allen, M. R.(2007) Promoting Student Resilience in School Contexts. Theory into Practice, 46(2) 162-169

10. McLaren, S.and Challis, C. (2009). Resiliency among men farmers: The protective roles of social support and sense of belonging in the depression-suicidal ideation relation. Death Studies, 33(3), 262-276

11. Uzma (2007). Relationship between academic resilience and academic achievement of Postgraduate students of University of Sargodha. Unpublished master's thesis. Sargodha, University of Sargodha

12. Wagnlid,G.M., Collins, J.A.(2009) Assessing Resilience. Journal of Psychosocial Nursing and Mental Health Services, 47(12): available on line at: http://www.jpnonline.com/view.asp?r (accessed on 18 January 2010) 
NOTES 